\title{
Teaching medical ethics and law within medical education: a model for the UK core curriculum
}

\author{
Consensus statement by teachers of medical ethics and law in UK medical schools *
}

The General Medical Council has stated that medical ethics and law should constitute one of the core components of the medical curriculum. ${ }^{1}$ The practice of good medicine inevitably raises both ethical and legal issues and demands an understanding of both. In this document, teachers of medical ethics and law in medical schools throughout the UK now offer their own consensus statement about the issues, concepts, arguments, skills and attitudes that all medical students should understand and know how to apply in practice by the time they qualify. This consensus proposes a minimal core undergraduate programme of work which we believe to be consistent with the stated objective of the General Medical Council that students should acquire a knowledge and understanding of "ethical and legal issues relevant to the practice of medicine" and an "ability to understand and analyse ethical problems so as to enable patients, their families, society and the doctor to have proper regard to such problems in reaching decisions". ' Some organisational principles are also summarised which we believe to be crucial for the successful implementation of our proposed undergraduate programme.

\section{Medical ethics and law in the medical curriculum}

Within the traditional medical curriculum, the teaching of ethics and law has often been both eclectic and scarce. If they were lucky, students received a few lectures during the entirety of their clinical studies - sometimes accompanied by small group discussions. The tutor might or might not have had academic qualifications or other relevant experience in either moral philosophy, moral theology or law. Such teaching was and sometimes still is optional, not formally assessed on a par with other clinical studies and not necessarily even for-

«This consensus statement is also available at the British Medical fournal website: www.bmj.com mally timetabled. As a result, attendance was afrd sometimes still is poor and audiences seifselected. The impact of such teaching on the rost of the clinical curriculum could be - unsurprisingly - sub-optimal. At some schools, however, where teaching has been more extensive and sostematic, student feedback is good.

The curriculum proposed here demands a b\$ anced, sustained, academically rigorous and clinically relevant presentation of both ethics and law in medicine, and of the relationship and tensions between them. Clinical relevance and the dutiges and educational needs of students should क्षेe stressed. Teaching should reinforce the oveall aims of medical education: the creation of gog d doctors who will enhance and promote the heath and medical welfare of the people they servegin ways which fairly and justly respect their dignity, autonomy and rights. These goals will be achieved through:

- ensuring that students understand the ethióal principles and values which underpin the practice of good medicine

- enabling students to think critically about etfical issues in medicine, to reflect upon their on beliefs about ethics, to understand and apprestiate alternative and sometimes competing approaches and to be able to argue and counterargue in order to contribute to informed discussion and debate

은

- ensuring that students know the main professional obligations of doctors in the United Kingdom as endorsed by the institutions whioh regulate or influence medical practice - partie larly those specified by the General Medical Council

- giving students a knowledge and understaxding of the legal process and the legal obligations of medical practitioners sufficient to ena迎le them to practise medicine effectively and minimal risk 
- enabling students not only to enjoy the intellectual satisfaction of debates within medical ethics and law but also to appreciate that ethical and legal reasoning and critical reflection are natural and integral components in their clinical decision-making and practice

- enabling students to understand that ethical and legal issues arise not only in extra-ordinary situations in medicine but also occur in everyday practice.

\section{Core content}

There is widespread agreement about the acceptable ethical and legal contours of good and safe medical practice and little debate about the related understanding, attitudes and skills that this requires. Relevant issues, problems, concepts and arguments are now explored in standard textbooks of medical ethics, in introductions to medical law and in much professional literature. Students must learn sensitively to apply their growing intellectual understanding of the ethical and legal underpinning of good practice in their evolving clinical experience and in their own professional relationships with patients, other health professionals and other members of society.

The following is a core list of topics which should be covered:

\section{INFORMED CONSENT AND REFUSAL OF TREATMENT}

- The significance of autonomy: respect for persons and for bodily integrity

- Competence to consent: conceptual, ethical and legal aspects

- Further conditions for ethically acceptable consent: adequate information and comprehension, non-coercion

- Treatment without consent and proxy consent - when and why morally and legally justifiable

- Assault, battery, negligence and legal standards for disclosure of information

- Problems of communicating information about diagnosis, treatment and risks: the importance of empathy.

II THE CLINICAL RELATIONSHIP - TRUTHFULNESS, TRUST AND GOOD COMMUNICATION

- The ethical limits of paternalism towards patients

- The significance of honesty, courage, prudence and facilitative attitudes: virtues in the practice of good medicine

- Legal and ethical boundaries of clinical discretion to withhold information

- Practical difficulties with truth-telling in medicine: inter/intra professional conflicts and other barriers to good communication
- The ethical and legal importance of good communication skills and the significance of the patient's narrative (as distinct from other professional narratives) in building relationships of trust. The importance of cultural, gender, inter-generational, religious and racial sensitivity.

III CONFIDENTIALITY AND GOOD CLINICAL PRACTICE

- Professional information, privacy and respect for autonomy

- Trust, secrecy and security in the sharing of information: the practical demands of good practice.

- The patient and the family: potential moral and legal tensions

- Disclosure of information: public versus private interests

- Compulsory and discretionary disclosure of confidential information: professional and legal requirements.

IV MEDICAL RESEARCH

- Historical and contemporary examples of abuses of medical research

- Individual rights and moral tension between the duty of care to the individual and the interests of others. Therapeutic and nontherapeutic research

- Professional and legal regulation of medical research.

- The ethical significance of the distinction between research, audit and innovative and standard therapy as well as between patients and healthy volunteers

- Research and vulnerable groups: ethical and legal boundaries of informed and proxy consent

- Research on animals: ethical debates and legal requirements.

\section{HUMAN REPRODUCTION}

- Ethical debates about, and the legal status of, the embryo/fetus

- The maternal-fetal relationship: ethical tensions

- Abortion: professional guidelines, legal requirements and debates about the use of tissue from aborted fetuses

- Sterilisation: ethical and legal issues

- Pre and postnatal screening and testing: ethical issues concerning informed consent and the determination of the interests of the future child

- Assisted conception: legal boundaries and ethical disputes. 
VI THE 'NEW GENETICS'

- Gene therapy: ethical issues concerning the distinction between treating the abnormal and improving the normal

- Somatic versus germline treatment and research: ethical and legal arguments

- Eugenics versus patient-centred care

- Genetic counselling: responsibilities to patients versus responsibilities to families

- Benefits and dangers of genetic testing and screening after birth: the risks of unwelcome information and of genetic stigmatisation

- Cloning: genetic versus personal identity ethical implications.

VII CHILDREN

- Respect for the rights of children: evolution of current ethical issues

- The relevance of age in the determination of competence to consent to or refuse treatment

- Ethical debates about legal boundaries of consultation with younger and older children as regards consent to treatment

- The doctor/parent relationship: proxy decisionmaking and protecting children's interests

- Good ethical and legal practice in reporting suspected child abuse.

VIII MENTAL DISORDERS AND DISABILITIES

- Definitions of mental disorders, mental incapacity, (including mental illness, learning disability and personality disorder)

- Ethical and legal implications of serious mental illness: civil incapacities, vulnerability and reduced responsibility

- Treatment, legal detention of, and research on, the seriously mentally disordered with or without consent

- Patient, family and community: ethical and legal tensions.

IX LIFE, DEATH, DYING AND KILLING

- Palliative care, length and quality of life and good clinical practice

- Attempting ethically to reconcile non-provision of life-prolonging treatment with the duty of care: killing and letting die, double effect, ordinary and extra-ordinary means

- Withholding and withdrawing life-prolonging treatment - and potentially shortening life - in legally acceptable ways

- Euthanasia and assisted suicide: ethical and legal arguments

- Transplantation: ethical and legal issues

- Death certification and the role of the coroner's court.
$X$ VULNERABILITIES CREATED BY THE DUTIES OF DOCTORS AND MEDICAL STUDENTS

- Public expectations of medicine: difficulties dealing with uncertainty and conflict. Ethiceal importance of good inter- and intra- professional communication and teamwork

- The General Medical Council. Professio regulation, standards, and the Medical Regisster. Implications for students and their relatiơnship with patients

- Responding appropriately to clinical mistakes: personal, legal and ethical responsibilities. Unethical and unsafe practice in medicige: "whistleblowing"

- The law of negligence, NHS complaints in disciplinary procedures

- The health of doctors and students and $\vec{d} s$ relationship to professional performance: ris\$s, sources of help and duties to disclose.

- Medical ethics and the involvement of doct in police interrogation, torture and cap punishment.

XI RESOURCE ALLOCATION

- Inadequate resources and distributive justoe within the National Health Service (NHS): 噢e law

- Theories and criteria for equitable health ca解:

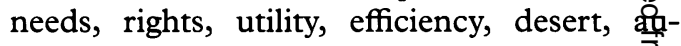
tonomy

- Debates about rationing: personal, local, national and international perspectives. Markests and ethical differences between competimg health care delivery systems

- Boundaries of responsibility of individuals for their own illnesses and ethical implications.

\section{RIGHTS}

- Conceptions of rights - what are they?

- Links between rights and duties and responsibilities

- International declarations of human rights

- The importance of the concept of human rights for medical ethics

- Debates about the centrality of rights for gof professional practice in medicine

- Rights and justice in health care.

The specification of these core issues is in no meant to beg questions about how they are introduced, discussed and analysed throughout curriculum. For example, some teaching pepgrammes will be more directed towards ethioal than legal analysis; others more focused on so issues (for example, informed consent) than others (resource allocation). Which foci are selected will and should depend in part on interests of lecturers and their clinical colleagues. 
In the specification of the "core" it would be wrong excessively to determine its specific content. For example, no specific texts or readings are recommended, but all the topics specified ought to be addressed.

\section{The general organisation of clinical teaching in ethics and law}

Success in presenting such a core programme within a general clinical curriculum entails more than getting the content right. There are also organisational prerequisites:

- Ethics and law applied to medicine is now an emerging academic discipline with intrinsic and rigorous standards. While teaching of this subject will and should be widely shared within medical schools, its adequate provision and coordination requires at least one full-time senior academic in ethics and law with relevant professional and academic expertise.

- Ethics and law should be introduced systematically in order to prepare students to meet their own professional and legal responsibilities when working with patients.

- Ethics and law teaching should be features of the whole curriculum, should begin early and be reinforced throughout the course. It should fully be integrated with the rest of the curriculum.

- Ethics and law teaching should also be integrated with the rest of the curriculum through provision of courses and workshops for teachers, including house officers.

- Ethics and law should be formally assessed as are all other core subjects within the curriculum. The details of such assessment will vary between schools but formal assessment should occur and should have the same importance as assessment in any other core subject. Without such assessment, ethics and law applied to medicine cannot be taught successfully within the medical schools. The teaching itself should also be assessed in the same way as is teaching in other core subjects.

- Ethics and law should have sufficient curriculum time and resources explicitly allocated to its teaching to achieve the preceding goals.

As part of its full integration into the curriculum, teaching in ethics and law should feature in the students' clinical experience, consistently forging links with good medical and surgical practice. Each clinical discipline should address ethical and legal issues of particular relevance to it and its students should be subject to assessment as they would be for any other teaching in that specialty.
Students should be encouraged to present problems which they have personally encountered in their course.

\section{TEACHING METHODS}

A variety of teaching methods is consistent with achieving the preceding goals. Ideally, these will entail a mix between large and small groups, exploring issues in a case-based fashion. Coverage of core material in ethics and law, however, should not falter in the face of insufficient teaching resources for small groups. Interactive work with large groups can still be effective and should always be considered rather than opting for little or no cover. The key is to make all teaching of whatever sized groups both clinically relevant and pitched to the academic background and ability of the audience taught.

\section{Conclusion}

We have outlined a core curriculum for the teaching of ethics and law applied to medicine and indicated organisational conditions for its successful teaching. We believe not only that it will help to create good doctors, but that it will help them to enjoy a more fulfilling practice of medicine in a world of diverse values and beliefs. We thus commend this consensus statement to the medical schools for adoption as the basis for their teaching of ethics and law and to the General Medical Council. We emphasise that this proposed model sets out conditions deemed to be minimal for achieving the aim of creating doctors who will engage in good ethically and legally informed practice. Many schools may wish to do more than we have outlined and this is to be commended. We believe that they should not do less.

\section{Those responsible for creating the core consensus statement on medical ethics and law teaching}

Dr Richard Ashcroft, Lecturer, Ethics in Medicine, University of Bristol

Professor Dennis Baron, part-time tutor in Medical Ethics (Rtd), St Mary's Hospital Medical School

Professor Solomon Benatar, Visiting CoDirector, Centre for Medical Ethics, University College London and Royal Free Hospital School of Medicine; and Professor of Medicine, University of Cape Town, Republic of South Africa

Dr Susan Bewley, Director of Obstetrics/ Honorary Senior Lecturer, United Medical and Dental Schools of Guy's and St Thomas's Hospitals, London 
Dr Kenneth Boyd, Senior Lecturer in Medical Ethics, University of Edinburgh

The Rev'd Jeremy Caddick, Dean of Emmanuel College, University of Cambridge

Professor Alastair Campbell, Professor of Ethics in Medicine, University of Bristol

Dr A Cattan, Lecturer in Medicine, University of Newcastle upon Tyne

Dr Graham Clayden, Reader in Paediatrics, United Medical and Dental Schools of Guy's and St Thomas's Hospitals, London University

Dr Albert Day, Senior Medico-Legal Adviser, Medical Protection Society

Dr Maria Dlugolecka, Consultant in Public Health Medicine and Honorary Senior Lecturer, University of Edinburgh

Dr Donna Dickenson, Leverhulme Senior Lecturer in Medical Ethics and Law, Imperial College School of Medicine, London University

Professor Len Doyal, Professor of Medical Ethics, St Bartholomew's and The Royal London School of Medicine and Dentistry, London University

Dr Heather Draper, Lecturer in Bioethics, University of Birmingham

Dr Bobbie Farsides, Lecturer in Medical Ethics, King's College School of Medicine and Dentistry, London University

Dr Martin von Fragstein, Lecturer in General Practice, Queen's Medical School, University of Nottingham

Professor Ken Fulford, Professor of Philosophy and Mental Health, Oxford and Warwick Universities

Professor Raanan Gillon, Professor of Medical Ethics, Imperial College School of Medicine, London University

Dr Danë Goodman, Medical Educational Adviser, United Medical and Dental Schools of Guy's and St Thomas's Hospitals, London University

Ms Vivienne Harpwood, Senior Legal Lecturer, Cardiff Law School, University of Wales

Professor John Harris, Sir David Alliance Professor of Bioethics, Institute of Medicine, Law and Bioethics, Manchester University

The Rev'd Peter Haughton, Adviser in Medical Ethics and Law, United Medical and Dental Schools of Guy's and St Thomas's Hospitals, London University

Dr Peter Healy, Honorary Tutor, Department of Biomedical Science and Ethics, University of Birmingham Medical School

Professor Roger Higgs, Professor of General Practice and Primary Care, King's College School of Medicine and Dentistry, London University
Dr Anthony Hope, University Lecturer in Prat tice Skills, University of Oxford Clinical Schooe

Dr Jennifer Jackson, Senior Lecturer, Department of Philosophy, University of Leeds

Dr Ian Jessiman, Elected member of Gene밈 Medical Council

Professor Alan Johnson, Professor of Surge University of Sheffield

The Rev'd Dr Jennifer King, Honorary Lêeturer in Ethics, St Bartholomew's and The Royal London School of Medicine and Dentistry, London University

Dr Steven Lutrell, Senior Registrar, University College, London University

Professor Eric Matthews, Professor of Philosi phy, University of Aberdeen

Dr Richard Meakin, Senior Lecturer in Genegal Practice, Royal Free Hospital School of Mediciree, London University

Dr Michael Parker, European Coordinator fer Biomedical Research Project, Imperial Colle School of Medicine, London University

Dr O Portsmouth, Honorary Senior Clinige Lecturer, University of Birmingham

Dr Lisa Schwartz, Lecturer in Philosophy of Medicine, University of Glasgow

Dr Francoise Shenfield, Clinical Lecturer Obstetrics and Gynaecology and Honorary L turer in Medical Ethics, University College London Medical School, London University

Dr David Snashall, Senior Lecturer in Occupational Medicine, United Medical and Dental Schools of Guy's and St Thomas's Hospitâts, London University

Ms Ann Somerville, Head of Medical Ethios, British Medical Association

Dr Timothy Steiner, Reader in Neurosciencês, Imperial College School of Medicine, London University

The Rev'd Bryan Vernon, Lecturer in Heath Care Ethics, University of Newcastle upon Tyne

$\mathrm{Mr}$ Christopher Ward, Consultant Plastisc Surgeon and Honorary Senior Lecturer in Medjical Ethics, Imperial College School of MediciRe, London University

Dr Luke Zander, Senior Lecturer in Depa $\frac{\sigma}{6}$ ment of General Practice, United Medical amd Dental Schools of Guy's and St Thomas's Hospitals, London University

Dr Paquita de Zulueta, Lecturer in Mediöal Ethics, Imperial College, London University

\section{References}

1 General Medical Council. Tomorrow's doctors. London: Gengral Medical Council 1993:14,26.

\section{ס्व}

